\title{
SMART-COMPLEX IN THE VOCATIONAL TRAINING OF A MODERN TEACHER
}

\author{
Iryna Smyrnova ${ }^{1}$, Kateryna Dovhopolyk ${ }^{2}$
}

1 Doctor of pedagogical sciences, prof. Department of Mathematics, Informatics and Information Activity Izmail State University of Humanities, Ukraine, https://orcid.org/0000-0003-2085-5391, e-mail: phd.smyrnova@gmail.com

2 Graduate student, lecturer at the Department of Mathematics, Informatics and Information Activity Izmail State University of Humanities, Ukraine, https://orcid.org/0000-0001-5636-5701, e-mail: kattdov@ gmail.com

\begin{abstract}
.
Relevance. The transformation and development of modern information technologies (IT) have affected the educational process of all educational institutions, which makes it necessary to justify the application of numerous pedagogical innovations using IT in the vocational training of future teachers. This makes developing important for future educators to understand the SMART-complex as a component of the information education environment, since in order to develop the SMART-complex, the teacher must understand its`structure and the interaction of all components.

Purpose: to highlight and characterize the main elements of the SMART-complex as an educational information environment of an educational institution, to prove the advisability of their use in the training of future teachers.

Methods: direct analysis and synthesis are for substantiating the relevance of the problem, that is under consideration; deduction is for identifying the main structural elements of the SMART-complex, modelling is for the image of the structural appearance of the SMART-complex, generalization is for taking the stock of the work.

Results: the emergence of the concept of the SMART-complex and some elements of its structural type were analysed; the existing SMART-complex models were described and generalized and their main structural elements were defined; the need to introduce SMART-complex as a component of the information education environment was noted.

Conclusions: SMART-complex is an information dynamic system of educational and methodological direction with defined SMART-criteria (specific, measurable, attainable, relevant, time-bound), with static, dynamic and environmental components; SMART-cloud resource is a system for personalized delivery and processing of electronic content; services (e.g., cloud-based electronic storage) for handling documents, spread sheets, electronic presentations; video-web conferencing for creation of electronic questionnaires, tests; application of this resource allows to organise both general and individual work with the content, in fact SMART-cloud resource is a «core» of SMART-complex; available SMART-complexes correspond to the modern educational needs in the context of fulfilling the tasks of the New Ukrainian School and can be used in the training of future teachers.
\end{abstract}

Keywords: SMART-complex, informational educational environment, concept of SMART-complex, SMART-textbook, intellectual learning, components of SMART-complex.

Introduction. A concept of a "SMART-complex" has appeared relatively recently in Ukrainian pedagogical science. This term was coined by the scientists of the Institute of Vocational and Technical Education of The National Academy of Educational Sciences of Ukraine, and a structural type of SMART-complex in the information environment of the educational institution was proposed. However, the world community knows these complexes are known as "smart" learning environments. Of course, SMART-complexes use a whole range of digital technologies to support educational activities and innovative methods of creating of the educational environment.

At the moment information technologies (IT) are being actively changed, improved and introduced into the educational process of all educational institutions. Therefore we consider it necessary to give 
teachers a basic understanding of main elements of the structural type of SMART-complex as a component of the informational and educational environment. For qualitative development of the complex it is necessary to fully understand the need to use a certain component. Considering the fact that the informational educational environment and the smart environments are receiving increasing attention of the research community, there are certain problems with terminology (How is "smart" learning different from the traditional one? What is the structure of a reasonable learning environment?). Equally important are the standards that smart environments must meet, since having a reference model we can draw conclusions about the quality of a work one or another environment and the innovation of subsequent developments in that direction.

References. IT technologies in the structure of education have been studied by Lapinskyi V. V., Kademiia M. Yu., Makarenko L. L., Miziuk V. A., Morze N. V., Pryhodii M. A. The information environment issues and systems have been researched by Bazelyuk O. V., Bakhmat N. V., Kartashova L. A., Lytvynova S. H., Smyrnova I.M., Plish I. V., Yashanov S. M. The structure of SMART-complex has been analyzed by national scientists (Bykov V. Yu. Voloshyna T. V. Hurzhii A. M. Hlazunova O. H. Kononenko A. H. Lypska L. V. Pinchuk O. P. Pryhodii M. A. Spirin O. M.), and foreign scientists (T. El, J. Mason, R. Koper, etc.). Ukrainian researchers (O. Hurzhii, A. Zuieva, A. Kononenko, L. Lypska, O. Prokhorchuk, M. Pryhodii) have also developed a model of SMART-complex as a component of the informational educational environment of the institution of professional (vocational-technical) education. However, the individual components of this model require some refinement. After analysing the works of famous Ukrainian scientists and researchers V. Bykov (2020), A. Hurzhii (2018), I. Smyrnova (2020), S. Yashanov (2019), A. Kononenko (2020), L. Makarenko (2020), M. Pryhodii (2020) and others in developing the information educational environment and electronic educational resources, we have come to the conclusion, considering the need for modern teachers to perform many functions simultaneously, the simplest model of SMARTcomplex should be created. The task of scientists is to optimize SMART-complexes on educational needs as much as possible and to justify their use in professional training of future educators.

The purpose of the article is to highlight and characterize the main elements of the SMART-complex as an educational information environment of an educational institution, to prove their usefulness in the training of future teachers.

Methods: direct analysis and synthesis are for substantiating the relevance of the problem that is under consideration; deduction is for identifying the main structural elements of the SMART-complex, modelling is for the image of the structural appearance of the SMART-complex; generalization is for taking the stock of the work.

Results and discussion. Digital education is implemented in the following areas: accessibility of technologies for pupils, teachers, administrators, educational Internet, multimedia-digital content, digital competence, literacy of teachers and pupils (Bazeliuk, 2018; Bykov, Spirin and Pinchuk, 2020; Yershov, 2019). The reform and development of the informational and educational space in Ukraine requires the deliberate development of a modern information and educational environment of higher education institutions, pedagogical and balanced design and use of computer-based methodical teaching systems, as well as corresponding improvements in the system of training and further training of pedagogical, scientific and educational personnel and managers (Bykov, Spirin and Pinchuk, 2020, p.28).

At present the world standards for SMARTcomplex design have not been developed yet. Scientists have been working in this direction but the work is far from being completed, because SMART-technology is a new form of interaction. Furthermore, it is constantly progressing. In 2018, Tore Hoel and Jon Mason (2018, p.11) researched intellectual learning and digital standardization. Their analysis shows that for both areas of analysis - research of intellectual learning and ITLET standardization - the conceptual development that establishes grounds to guide and encourage further development of the technology is necessary. They developed two models, a basic model of intelligent learning processes (Drawing 1) and a model of the characteristics of the environment in which intelligent learning takes place (Drawing 2). 


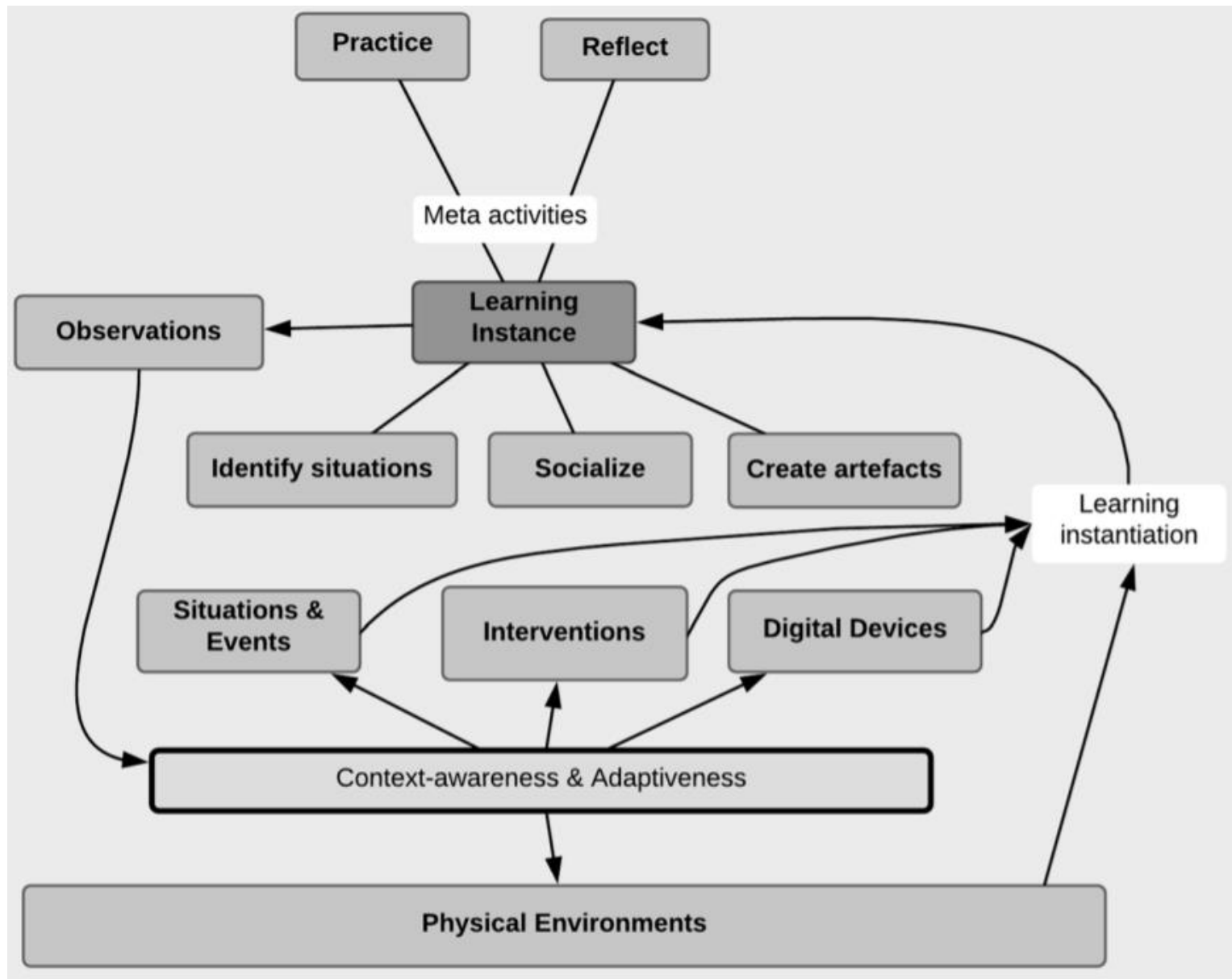

Drawing 1. Hoel and Mason Intelligent Environment Reference Model

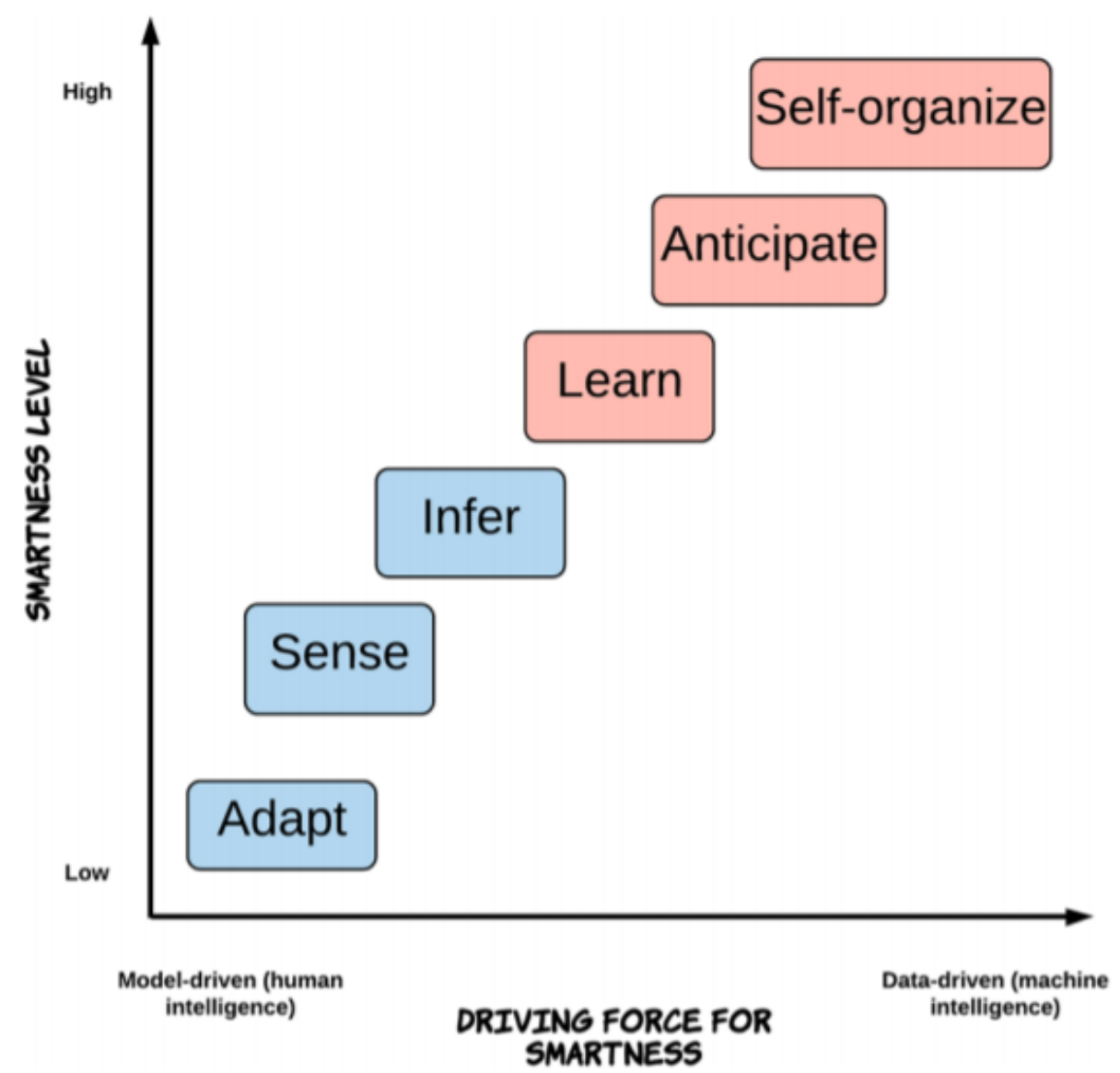

Drawing 2. Driving forces for different levels of reasonableness in the Human Learning Interface System (Hoel, Mason, 2018). 
Scientists have developed a basic reference model for a reasonable learning environment, based on the Koper concept introduced in 2014. The elements of the model can be described as follows: learning instance, i.e. a key element to be studied in the Human Learning Interface System is a unit of learning, involving the main activities represented in the learning and available through the Human Learning Interface System. A learning instance is created by introducing from the physical environment and other contextual influential factors, for example, the teacher defines the tasks and goals, sets the event, etc.; the teacher does the actions implying the use of digital devices. In order for the training to take place, the student must identify the situation (objectives, objectives of the training, schedule, etc.); the student must interact with other students, directly or indirectly; the student must create results for the translation of knowledge; the student must perform meta-activity through practice and reflexion.

The sensors of the intelligent educational environment monitor every activity of the subject; observations revert back to a context and adaptability mechanism that regulates input factors for subsequent learning. The conceptual work on intelligent learning was complemented by laboratory work on setting up and testing reasonable solutions in the classroom.
Research has shown that the more sophisticated Human Learning Interface Systems are, the more difficult it is to identify pedagogical practices, examples of used technologies and recognized standardization issues. One explanation for this observation is that the development of new learning technologies and new practices is a dynamic phenomenon.

The model presented in Drawing 2 describes the driving forces of smartness in a smart learning environment and the corresponding levels of smartness. Systems, that can adapt, feel and infer what is happening in a training scenario can also be based on human intelligence in real time, as well as on a system recorded as metadata ontology, student models, learning structure, etc. Systems begin to learn and take action without any human control, and then organize themselves and act as an independent agent in the learning scenario, and the system tends to be based on machine intelligence and run on big data. The model in drawing 2 complements their basic model. Although the first model describes how learning begins, the new model describes how learning environments are created - the context of learning and expected accomplishments (Hoel, Mason, 2018).

Gwo-Jen Hwang (2014) developed the concept of the structure of the intelligent learning environment.

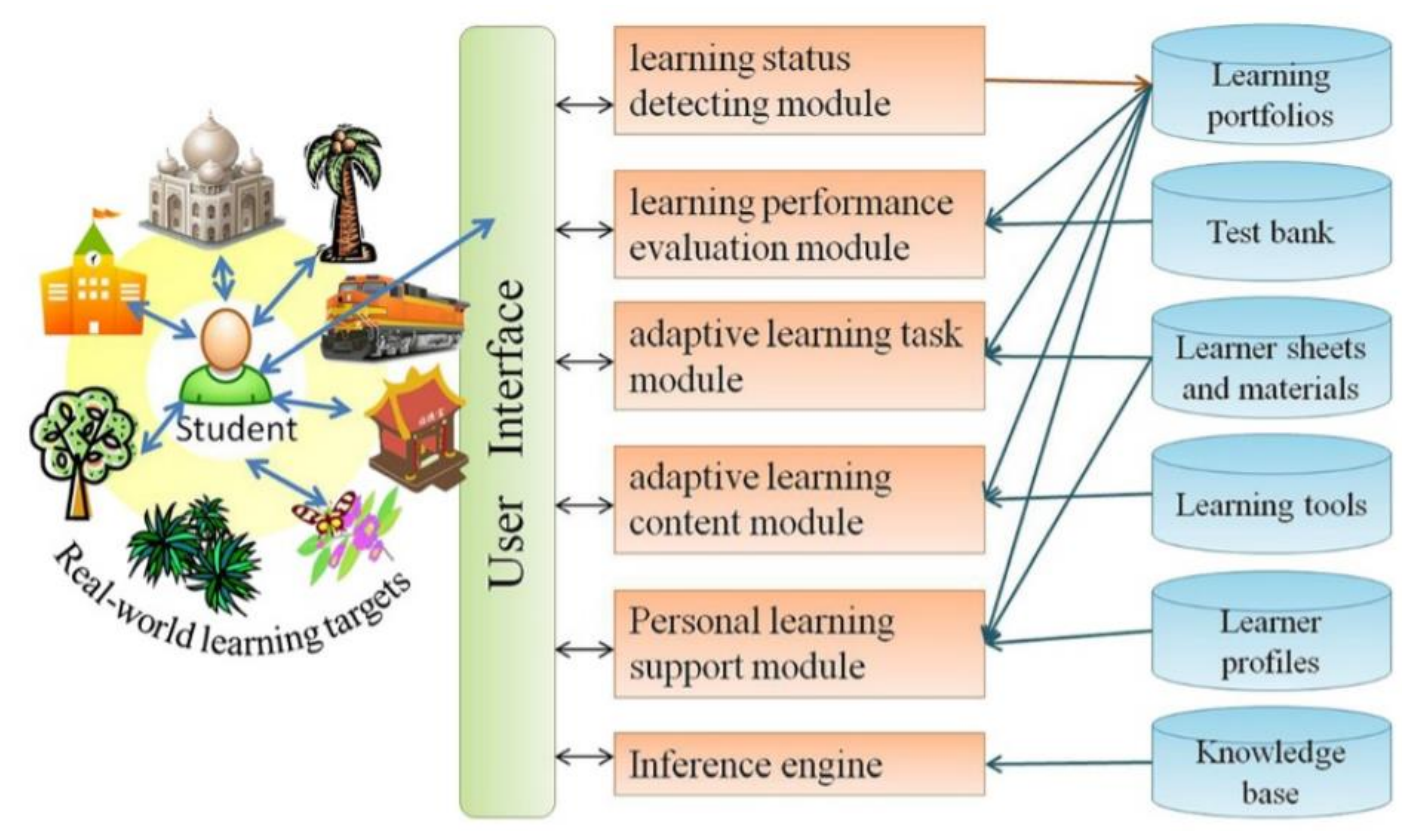

Wireless communication network

Drawing 3. Structure of the Gwo-Jen Hwang SMART learning complex

The scientist notes that SMART-complexes for learning are defined as minimally contextually dependent (only on the Internet and in the real world the state of learners' learning is considered as a context of learning), minimally adaptive (i.e., Professional Pedagogics/1(22)'2021 adaptive to emotional states, while cognitive abilities, motivation, socio-economic factors are not taken into account) and minimally personalized (i.e., pedagogical oriented guidance is not used) (Hwang, 2018). 
Certain Ukrainian scientists (Lypska, 2019, p.12) define the SMART-complex as a complex information dynamic system of educational and methodological direction, corresponding to SMART-criteria, which provides holistic information about the educational subject with the possibility of rapid access to educational content and a rapid assessment of training activities by participants in the training process. Principles of
SMART-complex system: interactivity, adaptability, and openness. It has a static, dynamic and ecological component and is distributed according to standard modules, which include a learning management system (LMS - learning management system), educational content, authoring tools (authoring tools), delivery system, the system of training and evaluation of educational applicants and participants (Drawing4) (Lypska, 2019, p.13).

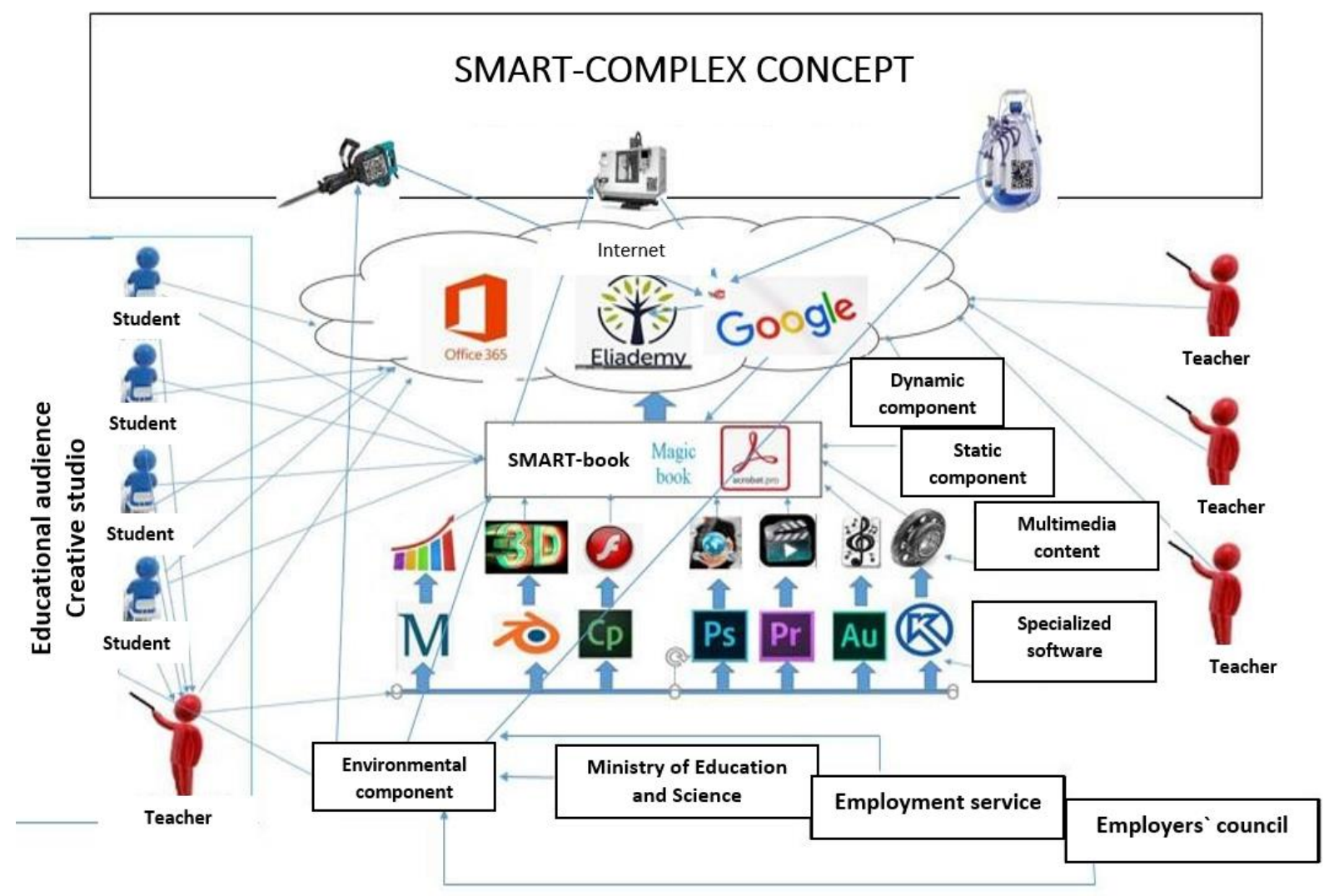

Drawing 4. SMART-complex concept

Learning management system (LMS) is a system that manages educational activities. The scope of the system is the development, management and dissemination of online training material, providing access to multiple users at the same time. The most famous LMS are: iSpring Online, Blackboard Learning System, Moodle, Adobe Captivate Prime, Google Classroom, etc. In the case of these systems, they also serve as a shell through which a user can access training programmes and courses. An advantage for the administrator in this case, thanks to this option, is the possibility to carry out operational control of the educational process in general (Miziuk, 2020, p.32).

Massive Open Online Courses (MOOC) are becoming more and more popular all over the world. The main advantages of these courses for the users are that they are free of charge, provided remotely and at the same time allow improvement of the program through such segments as intermediate tasks, tests, and final certification. Time limits and deadlines are set for the completion of tasks and courses, and it certainly motivates and further serves as a qualitative organization of the educational process. Now it is not the teacher who controls the process, but the student who will understand that if the task is not completed in time at one stage, they will have to start all over again. Quality platforms and pioneers of the sector are EdEra and Prometheus, which are well-known in our country. Among foreign platforms, it is worth mentioning Coursera, EdX, Udemyand Canvas Network (osvita.ua, 2020).

Authoring tools used in the development of educational content serve to create authentic educational materials. To the final educational product can be defined such forms as screen capture, electronic textbooks, course editors, questionnaires, presentations (and all for their creation), simulators, video trainings, tools for online seminars and tests. These development materials are available on the Learning 
Management System (LMS) platforms (The Best Learning Management Systems, 2020).

Scientists classify components of a SMARTcomplex into static and dynamic ones. Electronic textbooks are the most appropriate form for information that time has little or no influence upon. This is because they do not have time-dependent variables that can be updated according to scientific discoveries, research, and mainstream trends in the theoretical framework. Such content is called static or fixed component. The optimal content of an electronic textbook (based on the principle of the static component) can include, first of all, axioms, proven theorems and other information with the characteristics of a scientific constant. The second function of the electronic textbook should be offline access and options of the SMART-complex (if there is no internet connection) (Yashanov, 2019, p.43).

Cloud technologies and services, systems for distance learning online are considered to be the optimal way to provide the dynamic component. Alternative platforms for dynamically variable information content can be groups, chat rooms, pages in social media, specialized sites, etc. These platforms allow you to promptly submit and update information, to work with participants of the educational process according to the principle of «in-time» (Hurzhii, 2018, p.202).

The main objective of the environmental component is to transform the educational environment into a synergistic system using SMART-complexes. For this purpose developers and participants (moderators, administrators) of the educational process need to create a friendly environment for creation and introduction of innovations. Innovations will not only arise, but also cause public resonance, motivation for application and improvement, development (Smyrnova, 2017, p.291).

The structure of SMART-complex has the option of installing SMART-textbooks and SMART-modules. SMART-textbook is an Internet application that contains media files - graphics, videos, sound and text files, animation, 3D models, and anchor links. This type of electronic textbook contains the built-in option to be installed and synchronized with the platform - SMART-cloud resource and allows complementing the main content with educational SMART-modules (Kartashova, 2018, p.196).

The SMART- module is a holistic electronic content that displays a learning theme divided into subthemes. Like a SMART-textbook, it allows you to use different media files. The difference from the textbook (but not always) is the availability of navigation by sub-themes, time scale, test questions and links to other sections of the SMART-complex in the modules (Makarenko, 2013, p.102).

Such scientists as Bykov V.Yu. (2020), Pryhodii (2020), Kononenko A.H. (2020) developed the structure of the SMART-complex methodological system and found that the application of SMARTcomplexes in the methodological system of modern information and education technologies implies the identification and implementation of regularities, SMART-complex systems related to the interior ITinfrastructure, improvement of the IT knowledge and skills of the teacher (personal and professional qualities), improvement of the information culture of pupils and students, formation of a clear matrix of the knowledge system, skills, personal professional skills. The scientists have carried out a comprehensive description of the components, the regularity of the external relations of the system in the corresponding educational (educational-professional) environment (Pryhodii, 2020, p.111), on the basis of which the components in the educational environment of the educational institution have been developed:

- IT-subject component is a methodical system for the training of stundents, with the likely presence of components of different numbers depending on the class, the school profile and the level of the student; and these components can be at different levels of hierarchy and in different relationships;

- IT-locality - this methodological system should be developed taking into account the specifics of the region;

- IT-dynamism reflects the changes and development of SMART-components as a methodological system, depending on the demands of the labour market, society and the demands for innovation in education and science;

- IT-integrity implies the property of the components of the SMART-complex to have a clear purpose, place and related functions that serve the overall purpose of the IT-structure;

- structure is an important criterion for the evaluation and functioning of the SMART-complex methodological system, since it determines its effectiveness by analysing the properties of its structure and methods of validating evaluation;

- IT-focus is intended to be specific during the educational process and to be able to improve certain elements without disrupting the functioning of the SMART-complex;

- SMART-interdependence of the SMARTcomplex and the information and educational 
environment (the formation and development of the SMART-complex as a component of the methodological system takes place in interaction with the information and educational environment of the educational institution) (Kononenko, 2020, p.39).

The process of using SMART-complexes in the methodological system of modern information and education technologies is considered as complex pedagogical education with IT dynamic component, which is a set of interrelated components: objectives, forms, content, innovative methods, IT-technologies, comprehensive methodological support of vocational training, valid evaluation, self-educational activities of pupils and students (Drawing 5).

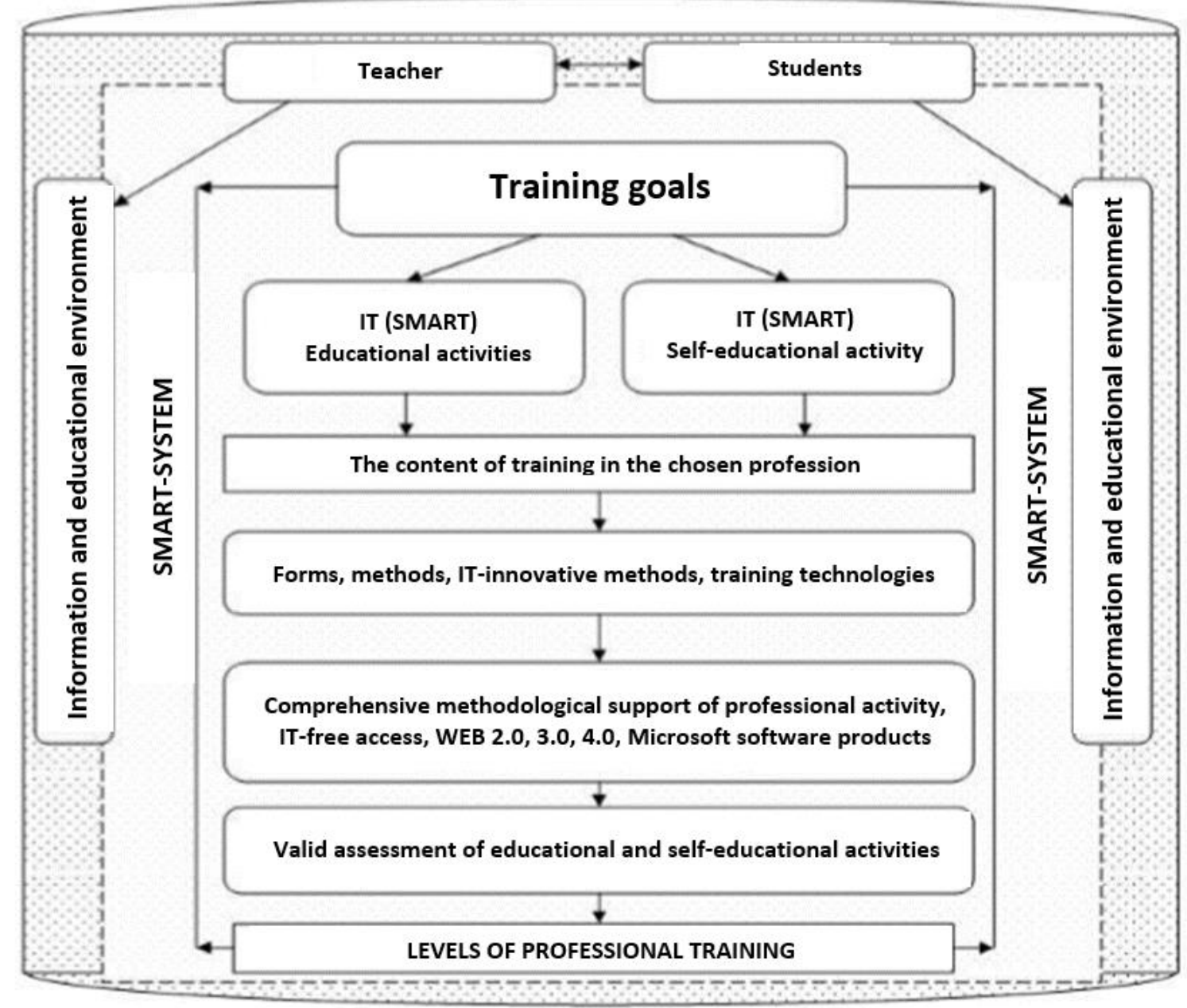

Drawing 5. Structure of the methodological system using the SMART-complex by Kononenko (2020, p. 40)

In our opinion this structure is useful for the development and design of SMART-complexes also for educational institutions.

Conclusions. SMART-complex is an information dynamic system of educational and methodological direction with defined SMART-criteria (specific, measurable, attainable, time-bound), with static, dynamic and ecological components. SMART-cloud resource is a system for personalized delivery and processing of electronic content; services (e.g. cloud-based electronic storage); working with documents, spread sheets, electronic presentations; videoconferences; for creating elec- tronic questionnaires, tests. Thus, by using this resource, it is possible to organise both general and individual work with the content, because in fact SMART-cloud resource is a "core" of SMARTcomplex.

After analysing the available concepts and models for information educational environments and SMART-complexes, we have come to the conclusion that they successfully meet modern educational needs in the context of the implementation of the tasks of the New Ukrainian School and can be recommended to use in the course of secondary school teacher training. 


\section{List of references}

Базелюк, О., 2018. Зміст і структура цифрової культури педагогічних працівників закладів професійної освіти. Науковий вісник Інституту професійно-технічної освіти НАПН України. Професійна педагогіка, 16, с. 81-87. DOI: http://doi.org/10.32835/2223-5752.2018.16.81-87.

Биков, В. Ю., Спірін, О. М. та Пінчук, О. П., 2020. Сучасні завдання цифрової трансформації освіти. Вісник Кафедри ЮНЕСКО «Неперервна професійна освіта ХХI століття», [online] 1, с. 27-36/ Доступно: https://www.unesco-journal.com.ua/index.php/journal/article/view/7/6 [Дата звернення 01 Травень 2021].

Гуржій, А. М., Глазунова, О. Г. та Волошина, Т. В., 2018. Використання хмарних електронних ресурсів і сервісів у навчанні IT-фахівців. В: Modern achievements of science and educations: XIII International conference. Netaniya, Israel, 6-13 September, 2018. Хмельницький: б. в, [online] с. 202. Доступно: http://elar.khnu.km.ua/jspui/bitstream/123456789/6643/1/MASE-2018.pdf\#page=203 [Дата звернення 11 Травень 2021].

Єршов М. О., 2019. Сучасні проблеми формування цифрової компетентності учнів у закладах загальної середньої освіти. В: Інформаційно-ичифровий простір України: трансформачійні прочеси і перспективи розвитку. Матеріали методологічного семінару НАПН України. 4 квітня 2019 р. / За ред. В.Г. Кременя, О.І. Ляшенка; укл. А.В. Яцишин, О.М.Соколюк, с. 79-85.

Карташова, Л. А., Бахмат, Н. В. та Пліш, І. В., 2018. Розвиток цифрової компетентності педагога в інформаційно-освітньому середовищі закладу загальної середньої освіти. Інформаційні технології $i$ засоби навчання, [online] 68 (6), с.193-205. Доступно: https://core.ac.uk/download/pdf/162002579.pdf [Дата звернення 12 Травень 2021].

Кононенко, А. Г. та Масліч, С. В., 2020. Використання SMART- комплексів у методичній системі сучасних інформаційно-освітніх технологій. Освіта та педагогічна наука, 1 (173), с. 37-46. DOI: https://doi.org/10.12958/2227-2747-2020-1(173)-37-46 [Дата звернення 11 Травень 2021].

Липська, Л. В., Зуєва, А. Б. та Прохорчук, О. М., 2019. Методичні рекомендації з розроблення SMART-комплексів для професійної підготовки кваліфікованих робітників будівельної галузі. Житомир: «Полісся».

Макаренко, Л. Л. та Шпильовий, Ю. В., 2020. Особливості застосування технологій комп'ютерного моделювання при вивченні дисциплін інформатичного циклу майбутніми педагогами професійного навчання. Науковий часопис Національного педагогічного університету імені М. П. Драгоманова. Серія 5 : Педагогічні науки : реалї̈ та перспективи : зб. наук. Праџь, 75 (т.1), с. 125-131. DOI: https://doi.org/10.31392/NPU-nc.series5.2020.75.27.

Освіта.uа, 2020. Популярні платформи онлайн-курсів (МОOC), [online] (Останнє оновлення 29 Жовтень 2013) Доступно: http://osvita.ua/abroad/higher_school/distance-learning/37601/ [Дата звернення 11 Травень 2021].

Пригодій, М. та Криворот, Т., 2020. Використання мережевих навчально-методичних комплексів у фаховій підготовці майбутніх викладачів. Професійна педагогіка, [online] 1(20), pp.109-117. DOI: https://doi.org/10.32835/2707-3092.2020.20.109-117

Смирнова, I.M., 2017. Розроблення електронних освітніх ресурсів як складової інформаційного освітнього середовища навчального закладу. В: Науково-методичне забезпечення професійної освіти і навчання: збірник матеіалів ХІ всеукраӥнської науково-практичної конференції (звітної), присвяченої 25-річчю НАПН України. К. : ІПТО НАПН Украӥни., с. 290-292, [online] Доступно: https://www.ivet.edu.ua/images/docx/Thesis_18_04_17.pdf\#page=290 [Дата звернення 11 Травень 2021].

Яшанов, С. та Дзус, С., 2019. Розвиток дидактичних принципів у системі інформатичної підготовки учителя технологій при використанні технологій комп'ютерного моделювання. Освітній дискурс: збірник наукових пращзь, 11 (3), с. 41-53

Hoel, T. and Mason, J., 2018. Standards for smart education - towards a development framework. Smart Learning Environments, [online] 5 (3). DOI: https://doi.org/10.1186/s40561-018-0052-3 [Дата звернення 11 Травень 2021].

Hwang, GJ., 2014. Definition, framework and research issues of smart learning environments - a contextaware ubiquitous learning perspective. Smart Learning Environments. 1, 4. https://doi.org/10.1186/s40561$\underline{014-0004-5}$ 
Makarenko, L., Slabko, V., Kononenko, A., Musorina, M. and Smyrnova, I., 2020. Pedagogical aspects of ensuring the efficiency of education of Applicants of higher education institutions of Ukraine in the process of research of technical disciplines. Journal of Critical Reviews, 7 (13), p.116-118.

Miziuk, V., Gumennykova, T., Pankovets, V., Liapa, M., Gramatyk, N. and Drahiieva, L., 2020. Applying Instructional Design Methods to Improve the Effectiveness of Blended-Learning. International Journal of Management, 11 (5), pp. 31-42.

Elearning Industry, 2020. The Best Learning Management Systems (2020 Update), [online] Ailable at: https://elearningindustry.com/the-best-learning-management-systems-top-list [Дата звернення 11 Травень 2021].

\section{Translated \& Transliterated}

Bazeliuk, O., 2018. Zmist i struktura tsyfrovoi kultury pedahohichnykh pratsivnykiv zakladiv profesiinoi osvity [Content and structure of digital culture of VET institutions' teachers]. Naukovyi visnyk Instytutu profesiino-tekhnichnoi osvity NAPS Ukrainy. Profesiina pedahohika [Scientific herald of the Institute of vocational education and training of NAES Ukraine. Professional Pedagogy], 16, s. 81-87. DOI: http://doi.org/10.32835/2223-5752.2018.16.81-87, [in Ukrainian].

Bykov, V. Yu., Spirin, O. M. ta Pinchuk, O. P., 2020. Suchasni zavdannia tsyfrovoi transformatsii osvity [Modern problems of digital transformation of education]. Visnyk Kafedry YuNESKO «Neperervna profesiina osvita KhKhI stolittia» [Bulletin of the UNESCO Chair "Continuing Professional Education of the XXI Century"], [online] 1, s. 27-36/ Dostupno: https://www.unescojournal.com.ua/index.php/journal/article/view/7/6 [Data zvernennia 01 Traven 2021].

Hurzhii, A. M., Hlazunova, O. H. ta Voloshyna, T. V., 2018. Vykorystannia khmarnykh elektronnykh resursiv i servisiv u navchanni IT-fakhivtsiv [The use of cloud electronic resources and services in the training of IT professionals]. V: Modern achievements of science and educations: XIII International conference. Netaniya, Israel, 6-13 September, 2018. Khmelnytskyi: b. v, [online] s. 202. Dostupno: http://elar.khnu.km.ua/jspui/bitstream/123456789/6643/1/MASE-2018.pdf\#page=203 [Data zvernennia 11 Traven 2021].

Yershov, M.-O., 2019. Suchasni problemy formuvannia tsyfrovoi kompetentnosti uchniv u zakladakh zahalnoi serednoi osvity [Modern problems of formation of digital competence of students in general secondary education institutions]. V: Informatsiino-tsyfrovyi osvitnii prostir Ukrainy: transformatsiini protsesy i perspektyvy rozvytku [ Information and digital educational space of Ukraine: transformation processes and prospects of development]. Materialy metodolohichnoho seminaru NAPN Ukrainy. 4 kvitnia 2019 r. / Za red. V.H. Kremenia, O.I. Liashenka; ukl. A.V. Yatsyshyn, O.M. Sokoliuk, s. 79-85, [in Ukrainian].

Kartashova, L. A., Bakhmat, N. V. ta Plish, I. V., 2018. Rozvytok tsyfrovoi kompetentnosti pedahoha v informatsiino-osvitnomu seredovyshchi zakladu zahalnoi serednoi osvity [Development of digital competence of the teacher in the information and educational environment of general secondary education]. Informatsiini tekhnolohii i zasoby navchannia [Information Technologies and Learning Tools], [online] 68 (6), s.193-205. Dostupno: https://core.ac.uk/download/pdf/162002579.pdf [Data zvernennia 12 Traven 2021].

Kononenko, A. H. ta Maslich, S. V., 2020. Vykorystannia SMART-kompleksiv u metodychnii systemi suchasnykh informatsiino-osvitnikh tekhnolohii [The use of SMART-complexes in the methodological system of modern information and educational technologies]. Osvita ta pedahohichna nauka [Education and pedagogical science], 1 (173), s. 37-46. DOI: https://doi.org/10.12958/2227-2747-2020-1(173)-37-46 [Data zvernennia 11 Traven 2021].

Lypska, L. V., Zuieva, A. B. ta Prokhorchuk, O. M., 2019. Metodychni rekomendatsii z rozroblennia SMART-kompleksiv dlia profesiinoi pidhotovky kvalifikovanykh robitnykiv budivelnoi haluzi [Methodical recommendations for the development of SMART-complexes for the training of skilled workers in the construction industry]. Zhytomyr: «Polissia».

Makarenko, L. L. ta Shpylovyi, Yu. V., 2020. Osoblyvosti zastosuvannia tekhnolohii kompiuternoho modeliuvannia pry vyvchenni dystsyplin informatychnoho tsyklu maibutnimy pedahohamy profesiinoho navchannia [Features of the application of computer modeling technologies in the study of computer science disciplines by future teachers of vocational training]. Naukovyi chasopys Natsionalnoho pedahohichnoho universytetu imeni M. P. Drahomanova. Seriia 5 : Pedahohichni nauky : realii ta perspektyvy : zb. nauk. prats [Scientific journal of the National Pedagogical University named after Drahomanov. Series 5: Pedagogical 
sciences: realities and prospects: coll. Science. wash.], 75 (t.1), s. 125-131. DOI: https://doi.org/10.31392/NPU-nc.series5.2020.75.27.

Osvita.ua, 2020. Populiarni platformy onlain-kursiv (MOOC), [online] (Ostannie onovlennia 29 Zhovten 2013) Dostupno: http://osvita.ua/abroad/higher_school/distance-learning/37601/ [Data zvernennia 11 Traven 2021].

Pryhodii, M. ta Kryvorot, T., 2020. Vykorystannia merezhevykh navchalno-metodychnykh kompleksiv u fakhovii pidhotovtsi maibutnikh vykladachiv. Profesiina pedahohika [Professional pedagogy], [online] 1(20), rr.109-117. DOI: https://doi.org/10.32835/2707-3092.2020.20.109-117

Smyrnova, I.M., 2017. Rozroblennia elektronnykh osvitnikh resursiv yak skladovoi informatsiinoho osvitnoho seredovyshcha navchalnoho zakladu [The use of network educational and methodological complexes in the professional training of future teachers]. V: Naukovo-metodychne zabezpechennia profesiinoi osvity $i$ navchannia: zbirnyk mateialiv XI vseukrainskoi naukovo-praktychnoi konferentsii (zvitnoi), prysviachenoi 25-richchiu NAPN Ukrainy. K. : IPTO NAPN Ukrainy., s. 290-292, [online] Dostupno: https://www.ivet.edu.ua/images/docx/Thesis 1804 17.pdf\#page=290 [Data zvernennia 11 Traven 2021].

Yashanov, S. ta Dzus, S., 2019. Rozvytok dydaktychnykh pryntsypiv u systemi informatychnoi pidhotovky uchytelia tekhnolohii pry vykorystanni tekhnolohii kompiuternoho modeliuvannia [Development of didactic principles in the system of information training of technology teachers using computer modeling technologies]. Osvitnii dyskurs: zbirnyk naukovykh prats [Educational discourse: a collection of scientific papers], 11 (3), s. 41-53

Hoel, T. and Mason, J., 2018. Standards for smart education - towards a development framework. Smart Learning Environments, [online] 5 (3). DOI: https://doi.org/10.1186/s40561-018-0052-3 [Data zvernennia 11 Traven 2021].

Hwang, GJ., 2014. Definition, framework and research issues of smart learning environments - a contextaware ubiquitous learning perspective. Smart Learning Environments, 1, 4. https://doi.org/10.1186/s40561014-0004-5

Makarenko, L., Slabko, V., Kononenko, A., Musorina, M. and Smyrnova, I., 2020. Pedagogical aspects of ensuring the efficiency of education of Applicants of higher education institutions of Ukraine in the process of research of technical disciplines. Journal of Critical Reviews, 7 (13), p.116-118.

Miziuk, V., Gumennykova, T., Pankovets, V., Liapa, M., Gramatyk, N. and Drahiieva, L., 2020. Applying Instructional Design Methods to Improve the Effectiveness of Blended-Learning. International Journal of Management, 11 (5), rr. 31-42.

Elearning Industry, 2020. The Best Learning Management Systems (2020 Update), [online] Ailable at: https://elearningindustry.com/the-best-learning-management-systems-top-list [Data zvernennia 11 Traven 2021].

\section{SМАRТ-КОМПЛЕКС У ПРОФЕСІЙНІЙ ПІДГОТОВЦІ СУЧАС- НОГО ВЧИТЕЛЯ}

\section{Ірина Смирнова ${ }^{\mathbf{1}}$, Катерина Довгополик ${ }^{2}$}

1 доктор педагогічних наук, професор кафедри математики інформатики та інформаційної діяльності, Ізмаїльський державний гуманітарний університет, Україна, https://orcid.org/0000-0003-2085-5391, e-mail: phd.smyrnova@gmail.com

2 аспірантка, викладачка кафедри математики, інформатики та інформаційної діяльності, Ізмаїльський державний гуманітарний університет, Україна, https://orcid.org/0000-0001-5636-5701, e-mail: kattdov@gmail.com

\section{Реферат:}

Актуальність. Трансформація та розвиток сучасних інформаційних технологій (IT) вплинули на освітній процес у всіх закладах освіти, що зумовлює необхідність обгрунтування доцільності застосування численних 
педагогічних інновацій із використанням IT у професійній підготовці майбутніх учителів. Це актуалізує важливість формування у майбутніх педагогів розуміння SMART-комплексу як складової інформаційного освітнього середовища, оскільки для якісного розроблення SMART-комплексу вчителю потрібно розуміти його структуру та взаємодію всіх компонентів.

Meта: виокремити й охарактеризувати основні елементи SMART-комплексу як складової інформаційного освітнього середовища закладу освіти, довести доцільність їх використання у процесі підготовки майбутніх учителів.

Meтодu: прямий аналіз та синтез - для обгрунтування актуальності проблеми, що розглядається, дедукція - для виявлення основних структурних елементів SMART-комплексу, моделювання - для зображення структурного вигляду SMART-комплексу, узагальнення - для підведення підсумків роботи.

Результати: проаналізовано виникнення поняття SMART-комплексу та деяких елементів його структурного вигляду; охарактеризовано й узагальнено існуючі моделі SMART-комплексів та визначено їхні основні структурні елементи; наголошено на необхідності впровадження SMART-комплексів як складової інформаційного освітнього середовища закладу освіти.

Висновки: SMART-комплекс - це інформаційна динамічна система навчально-методичного спрямування 3 певними SMART-критеріями (specific, measurable, attainable, relevant, time-bound), зі статичною, динамічною та середовищною складовими; SMART-хмарний ресурс - це система персоналізованої доставки та опрацювання електронного контенту; сервіси (наприклад, хмарне електронне сховище) для роботи з документами, електронними таблицями, електронними презентаціями; відео-вебконференції для створення електронних опитувальників, тестів; застосування цього ресурсу дає змогу організовувати як спільну, так і індивідуальну роботу з контентом, адже фактично SMART-хмарний ресурс - це «ядро» SMART-комплексу; наявні SMART-комплекси відповідають сучасним потребам освіти в контексті виконання завдань Нової української школи і можуть використовуватися у процесі підготовки майбутніх учителів.

Ключові слова: SMART-комплекс, інформачійне освітне середовище, конщепт SMART-комплексу, SMART-підручник, інтелектуальне навчання, компоненти SMART-комплексу.

Received: 04 June 2021

Accept: 30 June 2021 